\title{
Vladimir Putin Era Russian Foreign Policy
}

\author{
Elnur Hasan Mikail, Muhsin Yilmazchoban \\ Department of Political Sciences and International Relations, Faculty of Economics and Administrative Sciences, \\ Kars Kafkas University, Kars, Turkey \\ Email: emikail@turansam.org
}

How to cite this paper: Mikail, E. H., \& Yilmazchoban, M. (2018). Vladimir Putin Era Russian Foreign Policy. Open Journal of Political Science, 8, 339-352. https://doi.org/10.4236/ojps.2018.84024

Received: April 19, 2018

Accepted: August 14, 2018

Published: August 17, 2018

Copyright $\odot 2018$ by author and Scientific Research Publishing Inc. This work is licensed under the Creative Commons Attribution International License (CC BY 4.0).

http://creativecommons.org/licenses/by/4.0/

\section{(c) (i) Open Access}

\begin{abstract}
The primary reason for the Putin's increasing popularity is the broke out of the Second Chechen War. Russia has not got a homogenous structure; she embodies 100 nations together with 16 autonomous republics and 30 autonomous regions. Such an existing number and the South Caucasia where the most Muslims lived created problems for the Moscow government. In 1991 and 1992, a war broke out in North Ossetia and Ingushetia; there happened tensions in the Daghistan and Bashkir Republic autonomous regions. In the independence referendum held in March 1992 in Tatarstan, one of the largest regions with a one million population, $61 \%$ vote in favor was pulled. The most serious one among them is Chechnya of which Russia tried to prevent the seperatist movement. The Russian-Chechen history is entirely full of wars and large scale cruelties. Collaborating with Germans in 1944 Stalin banished almost all the population into the Kazakhstan steppes. Thousands of Chechens endeavoured to survive then.
\end{abstract}

\section{Keywords}

Vladimir Putin, Russia, Foreign Policy, Domestic Policy

\section{Vladimir Putin Era Russsian Foreign Policy}

Eventually, Khrushchev gave back the rights of these people and allowed them to go back to their countries. A wide scale war broke out in 1994 and it continued till the declaration of cease fire in August 1996. The Chechen guerilla warriors did more than a combat against the conventional unity formations and the ammunition deployed by the Russians, and thousands of sufferers, mainly of the civils like before fought ceaseless till costing them countless financial loses (Behar, 1998).

After the dissolution of the Soviet Union, Russia underwent a few years perplexity period in the international relations. In the period when Andrey Kozirev, 
known as the most pro-Western minister ever, was the foreign affairs minister, there happened no serious problems between Moscow and Washington, especially in the years between 1991 and 1993 (Blank, 1998).

Russia followed a flexible line in the foreign politics for a while both because of the psychology of refusing her past and the hope for solving the economic problems with loans to be borrowed from the West. But, Russia did not get the credit support she expected. Moreover, the tendency of NATO's expansion towards east caused tension. It intensified the opposing party's anti-American tensions through the country (Brzesinski, 1998).

The thesis of "Russia is a big state" was often repeated. Moscow decided to "follow independent policy" (Mansur, 1999).

When the old chef of the International Intelligence Agency Yevgeni Primakov was the minister of foreign affairs in 1996, serious innovations were made in the Russian foreign policy. The longing for empire was mentioned again. Now, Moscow defends the multipolar world thesis henceforth. USA and Europe work up to make use of the conflicts between them and other countries and regions. The primary target is to fight against the Washington's being the sole super power of the world, and to create a resistance via provoking the other countries (Balci, 2002).

Within the context of this policy, Russia has strengthened the relations with China, India, and the Far East and Middle East countries again. Russia showed that she is ready to reinforce the political and military relations with countries such as Iran, Iraq, and Libya (Aslan, 1997).

Russia tries to reinforce the ties with the capitals which exhibited different attitudes from Washington toward Iraq and Yugoslavia issues. And, she has tried to reinforce the relations with France, England, and Germany lately. One of the most important dimensions of the Kremlin foreign policy is to prevent NATO's getting strong and its expansion toward east, and to reactivate the United $\mathrm{Na}$ tions that has been on decline lately, and to benefit from OSCE more actively as well (Brown, 1996).

Vladimir Putin, as the Foreign Affairs Minister of the term, Primakov stated a few years ago, emphasizes that the most important purpose of the Russian foreign policy is to reinforce the relations with the countries of the Commonwealth of Independent States (Buze, 2001).

Meeting with the leaders at the Commonwealth peak held in Moscow in January 2001, Putin seems intending to reinforce the Commonwealth of Independent States together with the new peak that is thought to be made in a short time (Cecen, 2002).

Russia intends to reinforce the use of the energy resources, mainly natural gas and oil effectively, to accelerate the arms trade, and to reinforce the bilateral and regional collaborations directed both to the members of the Commonwealth of Independent States and the country and regions she regards strategically important (Chase, Hill, \& Kennedy, 2000). 
This basic purpose is accepted not only by Putin but also the whole Russian leaders and people: "It must be proved that Russia is still one of the biggest countries of the world." (Cohen, 1994).

\section{1. "New Foreign Policy" of Russia}

The two most important concepts of the international policy according to Putin:

1) Realism

and

2) Pragmatism

In Russia "Yeltsin term" ended, "Putin term" has begun. Almost everyone shares this idea, but there are different comments and estimations on what it does mean.

While even the assimilation of the Yeltsin term was not so easy, it is rather hard to predict what Vladimir Putin will bring along and to what he will lead, who is regarded as "black box" by many political specialists. However, at the hearth of the recent developments and explanations made, it is possible to assert some basic approaches. What kind of innovations the Putin term will contribute to Russian foreign policy has been argued in various aspects (Cohen, 1994).

At the end of March one sentence explanation was made by the Russian Foreign Affairs Minister, Igor Ivanov: "In consequence of the election for the new president, certain changes will be made in Russia's foreign policy". This short expression raised a series of questions (Crell, 1990).

For that purpose, the Ministry of Foreign Affairs was assigned to the coordinator ship of all the international activities including Russia's foreign trade in the Security Council meeting that handled the Russia's new foreign policy concept in March 24, 2000. When considering the rumors from the lobbies, Russia seems determined to seek her foreign economic interests not in the West further but in the countries where the Russian products were in demand and Russia established relatively less relations and in the common markets of the Commonwealth of Independent States henceforth (Crozier, 2000).

\subsubsection{Realism Dimension}

Would the new formation in Russia bring along radical changes in the foreign policy of Moscow or will the old applications continue in exactly the same way? (Mansur, 1999).

Is Russia going to follow a "more aggressive" line in the international arena? Regulative Marxism is mostly the result of the later developments in the Soviet Russia. There are many debates about that Marxism was still among the different doctrines in Russia in the 1920s. The reproducing and imposing of the unchangeable doctrine, "Socialist Realism" was seen in 1932. The term contains a theory that demands the author, on the one hand, produce the truth correctly, a modern community, be realist in the sense of portraying it by understanding its structure, one the other reproduce the truth objectively and use his talent to expand socialism i.e. communism that has the party spirit and party line (Amy, 
1999).

The authoritive theorist stated that the Soviet literature must be an agency in shaping the masses working in socialism spirit", which was a similar statement of Stalin, "Authors are the engineers of the human spirit".

The most repeated word was Realism in the expressions of the official authorities on why the Russian foreign policy concept accepted in 1993 was invalid. Russia intended to place her foreign policy on the more realist grounds, and arrange it according to the domestic needs, especially to the economic goals (Behar, 1998).

\subsubsection{Pragmatic Theory, Pragmatism Concept and Pragmatist Foreign Policy}

Pragmatism, as a concept, tries to explore the communication systems among humans, animals and machines, and the relations in them by combining the various disciplines such as philosophy, linguistics, artificial intelligence, ethnology, cognitive anthropology, sociology. It tells to where and how the words coming out of mouth go. It is a philosophy arguing that everything could be explained following an "act". There is no cause, goodness, badness, truth; falsity in any thing, what is important is the result. Pragmatism is of the suitable platforms to look at many philosophies.

It is natural that the pragmatic idea shaped by John Stuart Mill in Englang, where the first growing area of the capitalist production type was, brought about Pragmatism that was founded by Charles Pierce (1839-1914) in America later on, and developed by William James (1842-1910). Thus, the metaphysic philosophy of capitalism was founded.

In his book Pragmatism James states, "It is too late to change it" for pragmatism. He dedicates his work to pragmatist Mill with these words: "To the memory of John Stuart Mill from whom I first learned the pragmatic openness of mind and whom my fancy likes to picture as our leader were he alive". Pragmatism, as James states, is a method more than being a philosophy, a method measuring the thought according to the act it produce. Charles Pierce, in his article "How to Make Our Ideas Clear" published in the Popular Science Monthly magazine in 1878, states as: "To develop its meaning, we have, therefore, simply to determine what habits it produces, and for what a thing means is simply what habits it involves".

William James, after twenty years, brought this word to light that noone interested in. William James says there is absolutely nothing new in the pragmatic method. "Socrates was an adept at it. Aristotle used it methodically. Locke, Berkeley, and Hume made momentous contributions to truth by its means. Shadworth Hodgson keeps insisting that realities are only what they are "known as". But these forerunners of pragmatism used it in fragments: they were preluders only. Not until in our time has it generalised itself, become conscious of a universal mission, pretended to a conquering destiny. I believe in that destiny, and I hope I may end by inspiring you with my belief" (Blank, 1998). 
The whole mission of philosophy is to understand what kind of a distinction that these or those world formulas are true will produce in us in certain moments of our lives. The Pragmatical method, before all, is the method which attempts the metaphysical arguments that will not end in any way. Is the world uniqe, or not? Is it bounded to destiny or free? Is it material or spirit? These are such concepts which are possible to be true about the world or not.

The arguments on such kind of concepts never end off. In such situations pragmatical method tries to interpret every concept by means of suggesting practical conclusions that will be estimated on them. If this concept were much truer than the other concepts what kind of a distinction would arise for any one else in the practical sense? If the conclusions made are of no practical difference the both two thoughts will be equal to the same thing in practical sense. In that case, the argument is senseless. If the argument is general it is required to see a practical distinction in case of that this or that is true. It means broadly: What if the world is material or spirit? If this or that provides a practical utility then it could be accepted.

Thus, William James chooses spirituality by using pragmatism as materialism is unnerving whereas spirituality is joyful, encouraging, and vital. Trust in God is a favorable act for people. This act provides people, in James words, a moral holiday. The thought of that the evils of the world perish in God makes us escape from the sense of responsibility. The fears could be overcome by relying on the goodness' victory. A moral holiday can be achieved by letting the world car go in its direction. If you say is it truth James' response is ready: truth is the one that has practical value (Chase, Hill, \& Kennedy, 2000).

Pragmatism, thus, is in the opinion of solving the disagreement between the rationalists and empiricists. By applying the ration's data on the pragmatic method pragmatism will both stay religious and deal with the phenomenon. As each of them contains practical value it does not separate them. No matter the empricist says "we do not believe" the God idea the pragmatist will continue to use it as long as he finds practical value.

According to the Pragmatists a thought is true as long as it is practical for our lives. "It is good" can be said in the place of "it is true" as these two concepts are the same. The word, truth is referred to everything that has proved well in the faith. The true one is good at the same time due to some reasons. If we asked what to believe would be better for us this means, what do we have to believe? (Cohen, 1994).

The answer of this question; we have to believe in that is better for us to believe. Now then, there is no difference between the one better and truer for us. Pragmatism combines the truth and good. This conclusion can be inferred from this: Virtue is true as long as it is beneficial for our living and in the conditions it provides practical value. Everything should be rated to the practical value degree; everything should be estimated according to practical value. For that reason, combining the beautiful with truth or good, the benefits of philosophy, science 
and art in one hand should be evaluated via applying them to the value degree as they have no difference with regards to practical value or practical valuelessness.

Pragmatists apply their methods both to the abstractionists and pre-empiricists. According to them the true thought is one that could be verified in practice. The truth of a thought is not an adhered, static characteristic. Truth happens to thought. A thought cannot be true while in your brain. However, it turns to be true, it becomes true through events. Its being truthful is when it becomes valid. We live in a world of endless valuable or harmful realities. Positive thought is important for us. When you get lost in a forest, if you are about to starve when you see something like a footpath it is very important for you to imagine a house in which people live. Here, the positive thought is valuable as to what it leads is valuable. The practical value of positive thought results from the practical values of the objects equivalent to that thought.

Truth is the thing valuable for us while thinking, just as right as valuable during actions. It is to find a theory necessary, suitable, manageable for people. So, pragmatism is just that theory. As it is seen, pragmatism is a nonscientific theory though it is expanded and approved in the bourgeosie world. It clearly denies science. As James says human in the world is like a cat in the library; he saw and hears but understands nothing (Buze, 2001).

Pragmatists shut their eyes to the objective reality of the world. Reality is determined according to our favors; it is subjective. Pragmatism was followed by Dewey, F.S. Schiller; it even took different shapes up to defend racism and fascism. Having addressed to the nation first time since he was elected in March, Putin, in his speech in the Russian Parliament, stated that Russia must be a powerful country and he would head for accomplishing this goal of the foreign policy.

Putin'in said, "That Russia is independent in the foreign policy could be claimed to some extent. Our foreign policy must be based on pragmatism; its economic efficiency must be assured and must attach priority to the national goals". Putin saying: "Freedom of expression will remain as the indispensible merit of the Russian democracy", accused the commercial media owners of employing media in fighting with each other and state and misinforming. Pointing out that they have to effort to purify Russia from the threats of terrorism Putin stated that terrorism harms the territorial integrity systematically.

Auerbach's realism is very special and maybe denier; according to him realism means a sense of existence that is conceived tragically in the eye of a lonesome facing both understanding the social and political reality and moral decisions (Behar, 1998).

\subsection{Russia's Allies}

In the election of $26^{\text {th }}$ March 2000 upon a ten-year freedom period lived after Tsardom of Russia and the rule of Communist Party, the old intelligence chef became the president winning the election over the leader of Communist Party. The dramatic end of the freedom period was not limited to who were the po- 
werful president candidates; it also put forth clearly that people wanted peace not democracy; welfare not freedom.

The issue upon which 12 president candidates agreed was that Russia should be remade a powerful state and Moscow should be proved still one the most important centers in foreign policy. The attitude of Putin, by the time just a month of his coming into power, entering into "Momerandum of Understanding" agreement with China, which was aimed at the improvement of the military cooperation between these two countries against NATO and USA, and selling to China destroyers that would enable them to compete with the American vessels in Taiwan Strait, higly discomforted the USA.

Though this discomfort was clearly expressed by the US Congress at the beginning of March the fact that Putin persisted in the military alliance with China encouraged the Chinese government. North Korea had been a target board for USA alongside China in the Asia-Pasific Region, and Putin's visit to North Korea that aimed the improvements of the military relations with North Korea, was another sign of Russia's challenge to USA after years (Ifrah, 1998).

The Middle East was another zone Putin attempted to reckon with the US. This area on which Russian imperialism had a great impact in Khrushchev and Brezhnev periods was lose to the US imperialism. The first act of Putin's policy of regaing the Middle East as a hegemony sphere was the undertaking of the protectorate roles with the states that had problems with the US. In this sense, through the Putin term some collaboration agreements were made with Iran, Iraq, and Lebanon in economic, and especially in the military fields (Blank, 1998).

\subsection{Innovations of the Putin's Russian Foreign Policy and Basic Reflections of the Russian Foreign Policy Concept}

Russian government accepted the Russia's new Security and Defense Doctrine in January 10, 2000. Before two days of the presidential elections, the foreign policy concept was negotiated and certain basic principles were determined. In the light of these two evaluations what kind of innovations would be seen in Moscow's international politics through the Putin administration could be summarized as:

1) More active foreign policy: Following a more creative and more enterpreneur line on a larger platform, restoring relations with old friends, offering suggestions to gain new ones (Crozier, 2000).

2) More open foreign policy: non-building the new "iron curtains" and "walls", collaboration with the West (Putin's restarting the relations with NATO became the first example), utilising the international organizations actively.

3) Independent foreign policy: Russia's maintaining an attitude according to her interests on any issue, not following in any state and state groups wake, not making concession on the long term acquisitions in favor of the economic and political short term acquisitions.

4) Foreign policy in the base of national interests: considering the interests of 
the Russian state firstly in political, economic, military issues, the protection of the Russian primarily living abroad, (it is guessed that about 840.000 Russians live abroad).

5) Pragmatical foreign policy:

a) The determination of what is important and necessary, what is unimportant and unnecessary in the international arena;

b) Not making conflicts with the West on the trivial issues, but utilising the international opportunities completely instead;

c) Elasticising the foreign affairs for the purpose of attracting foreigner entrepreneurs (Kapuscinski, 1999).

\subsection{The Illusions in the Russian Foreign Politics}

The famous politician, Galina Starovoitova who carried out the Caucasia consultant of Yeltsin till 1992 and was known of her sensitivities with human rights, was assassinated in 20 November 1998. Starovoitova was one of those defending self-determination in Chechnya. Before she was killed by a hired killer in front of her house in St. Petersburg she had explained that she would become a canditate for the presidential elections that would be held a short time ago (Chase, Hill, \& Kennedy, 2000).

Contemplating over the mafia-politics link and trying to bring out the dirty relations, Staravoita made the organized crime organs sitting targets. But, the main point that discomforted a few crime groups was her challenging attitude against the Russia's current policy about Chechnya and her boldness as to become a president candidate as the owner of this attitude. In the frame of this context, her assertive attitudes were found extremely bold (Brown, 1996).

The deep state in Russia would not forgive this venture and it did not anyway; A human rights defender woman politician fell victim to bullets. In fact, a part of iceberg related to the dirty relations world was seen before long and the money laundering scandal busted out. The scandal was hinged upon the Yeltsin term. Boris Yetlsin's daughters Tatiana Diachenko and Yelena Okulova, each one was an element of this crime (Cohen, 1994).

Galina Starovoitova condemned fiercely the genocide that Russia initiated against Chechnya in 1995, which had one in a hundred territory than Russia, and took the attention on the dilemma Kremlin got into. When Russia carried her plan into effect which she could not succeeded for a second time Starovoitova would definitely express her criticisms again. It was known that the Russian secret service and mafia were among the planners of this assassination (Crell, 1990).

It came out that Starovoitova had sent a letter to Dr. Tilman Zulen of Brown University Thomas J. Watson Jr. International Study Institute. In this letter Starovoitova had clearly expressed that she supported the self-determination of Chechnya's her own destiny. In her letter sent in January 15, 1995 there wrote, "Dear Mr. Zuley, I thank you for your positive attitude towards the Chechnya 
people, I agree with you, too (Aleksandrov, 1989).

I want to get more information about your institution. I am, too, one of the defenders of self-determination. I wrote my book last year, it is ready to be published now. And, I explained the terms of how this right would be put into practice. I liked your idea of the opening of Chechnya Embassy in Bonn symbolically; I support this idea as well."

This event showed that those who would criticise the Russia's political preferences could be a sitting target for the Federal Security Bureau (FSB) (Aslan, 1997).

\subsection{Putin's Domestic Policy}

Yet, it does not mean that they could not change it. The reflections of the distemper between the alliances we belonged to and Russia, the humanitarian plight in Chechnya is possible to be felt in Turkey. Most importantly, the perception of both two countries each other was overwhelmed by a historical burden (Ivanov, 2001).

Especially, when the Turks took lessons from the history of the relations, they did not take lessons from the collaborations but from the wars, grieves, and migrations. The history was not already regarded bright. The first relation between the two countries was established via the embassy committee in the leadership of Mihail Pleshcheyev, who was sent by Mengili Giray, the Crimean Ruler of Ivan III with the commercial purposes to Beyazit II, but in the upcoming centuries there happened wars more than trade. The first serious conflict happened because of the Chehrin Fort in Ukraine in 1678. It ended with the Ottoman army's taking the fort and killing of the 30.000 guardsmen in the fort (Crozier, 2000).

The steps for the collaboration were taken reluctantly. The July 8, 1883 dated Hunkar Iskelesi Treaty which proposed the mutual assistance was signed by the Sublime Porte for shrinking from the rage of Egypt Governor, Mehmet Ali. The reason for the special relations developed in the period between the two world wars was the desolateness of Turkey felt in that period. But now time changed. The empires ended. The "geopolitical" archaic is no more than a fantasy in today's world that multinational corporations mounted up. "The Big Game" turned out to the game of the journalists who could not realise the change. Even though most of us did not realise the Cold War ended even for Turkey as well. The visit of Ismail Hakki Karadayi, the Chief of General Staff of the time, to Russia in May 1998 recorded this ending (Amy, 1999).

There are strategical interest partnerships that have not been talked over between the two countries. A multipolar world is at least for the benefit of Turkey as much as Russia. Besides, it must not be forgotten that the 1936 dated Montreux Convention formed a common fate between each country. When it is thought that this convention would not revised due to any reasons and this would cause the free-passing of the warships through the Straits the power of the common fate would prove by itself. Russia, not wanting to see the 6th Fleet in 
the Black Sea, has to treat well Turkey. Beyond anything else, the commercial ties between the two countries have increased to an in expendable degree. Turkey in natural gas, Russia in money she will earn, has come to be in contact each other (Ifrah, 1998).

Naturally, it is possible that the interests may not intersect in every field. It impossible for Turkey to approve silently what happened in Chechnya and to accept what Russia did to strengthen her hegemony in Caucasia (Cherniavsky, 2000). What is more important is to make the competition in a way not forcing the collaboration, and to ground the evaluations on realities instead of prejudies in such issues as pipelines and oil. The first step of the New Russian leader was in the purpose of saving the Russian Federation and preventiing the dissolution of the state (like USSR) (Aktukun, 1995).

Beside the efforts of preventing Chechnya to part from the Federation some measures were taken against the other autonomous republics and units. The parliament upper house Federation Council, consisting of the leaders of the 89 administrative units, has been started to get removed de facto and to be turned into a more symbolic form. In the meantime, the new institution named State Council formed through the participation of the regional administrators has been kept as only consult organ position. The lower house of the Parliament, Duma is no longer dominant as it was in the past and opponent to the President. Notably "Union" fraction and except the parliamentary groups connected to Putin, the communists significantly have lost their old opponent characteristics and they have retreated to remain in the background. The leftist-liberal parties whose disunity the government utilized by caring for at times are not much active. Consequently, Putin totally has the command of the Russian in the political scene. Maybe the only opponent power in the country is in the media especially, notably NTV channel and in the "Media Most" broadcasting holding constitution (Cecen, 2002).

It is useful to touch upon Putin's attitude against the big business environments characterised as oligarch. The powers helping Yeltsin win the 1996 presidential elections began to affect Kremlin later on immoderately. Some of them have politician and/or media patron identities as well (Rose \& Munro, 2002).

Putin scared the businessman notably the ones cited above. He kept them distant from Kremlin. In the meantime, he restricted the freedom of the press de facto. But now he tries to show capitalists and press that he will not oppress them as long as they remain in the line Putin drew just like he emphasized that his purpose to establish "Big Russia" did not mean to return emperorship and the USSR. In addition, the fact how democratic the steps that Putin took against the autonomous republic and regional administrators, and business environments and media are not at issue in Russia because, as the surveys conducted within the recent years show "public order and security take precedence of the western democratic values" for the Russian people and the traditional pursuit of powerful and authoritarian leader is dominant in the society. 
The biggest advantage of Putin is his unbelievable popularity among the people. For the last one year, the popularity level of Putin was about $60 \%-75 \%$. Due to his deeds, he has substantially dominated the Russian political scene and the security organs. He has come a long way in making himself accepted among the world as well. He has been making up his lack of experience rapidly.

\subsection{Putin's Foreign Policy}

The basic foreign policy of the Putin's Russia is based on the "multipolar world thesis". This policy, suggested by Yevgeni Primakov afore, is seen in the elasticity as to address to the interets of the all countries excluding the USA. Eur-Asianism is at issue as a doctrine in Russia as well. Erol Mutercimler states about this issue as, "the Russian foreign policy remained between two opinions after the dissolution":

The pro-Atlantics Opinion that defends the integration with the West, and Eourasians Opinion that defends the necessity of turning back to the traditional values by stopping the reforms because of the fact that Russian people were drawn away from the Slavic identity by force by the reforms made in the time of Peter the Great.

Moreover, it could be asserted that Russia was settled on the lands which Halford Mackinder defines as geopolitical center no matter by whom it were governed, and is the successor of one of the most powerful emperorship traditions as well. Implying that the interruption of America in the domestic conflicts of Russia could trigger a nationalist counteraction, H. Kissinger claims "Could the US isolate both Russia and China at the same time and endure to regenerate the possibility of Chinese-Russian alliance in favor of its domestic preferences?" After stating that Fuller Islamist (anti-imperialist) movements could only be effective among the Muslims, H. Kissinger shows his fear by putting forth these fixings: it is possible to think that the other important states that are not content with statu quo may provide the domination to affect the world evolution via collaborating with and unofficial power and weaken the western monopoly felt in this order. In case of a government reshuffle, China, India, and even Russia are the potential leaders for the category of the countries that are the have-nots. In short and medium terms, as the reformation efforts of the old communist countries and many third world countries fails it should be hoped that a state or a group of states will try to be the leaders of the countries suffered from the new world order. Fuller accepted that the New World Order could not be good for everyone. The great lie of the imperialism has come out slowly. And, the imperialists have begun to feel anxious ever (Brzesinski, 1998).

\section{Conclusions}

Ariel Cohen, categorizing the interests of USA in Euroasia as security, political and economical ways, says, "The national interest of the US requires the stability of Euroasia." The chaos in Russia and CIS may threat the control over the nuclear powers holdover from the Cold War, it may collapse the reform-sided gov- 
ernments, and it may cause the nationalist anti-western regime formations. Cohen adds that the prevention of this possibility will be a big victory on behalf of free market.

All of these indicate that western imperialism, especially the USA is disturbed by the enhancement of the anti-imperialist movements within this area. In other words, they give us clue on what we should not do. According to the Eur-Asians, in case that they become a part of Europe Russia and the Russians have no chance to live as a nation, as a state. The Eur-Asians mostly composed of communists and ultra-nationalists see the interests of Russia in the east.

Zeynep Dagi summarizes this process as, "Reformists got weakened on account of their populist policies and shock therapy-like economic reforms." Upon all these developments, the group named the New Asians has had voice firstly in domestic policy and then foreign policy gradually. The New Asianists led by the senior military and civil bureaucrats accuse the reformists of being utopic; always emphasize the existence of an interest not companionship. They argue that the foreign policy could not be built on such concepts as democracy and human rights. They firmly criticise the policies that try to integrate the country's economy and the military structure into the West with the claim they would cause an asymmetrical addiction. They support multiple choice foreign policy that the attentions would turn towards such countries like China, India, and Iran instead of single choice foreign policy aimed at only West. We can see that the geopolitical reality of Russia plays an important role in the points of view of the New Asianists.

While looking at those writings above, a number of common points stand out with the discourses of those who defend the Eur-Asia option in real terms. While we, Kemalists, defend our national interests, the New Asianists in Russia (or the Eur-Asianists) defend their own national interests.

The Eur-Asianists in the both countries should seek the ways of a regional cooperation in the second phase to carry through a stronger resistance after having detected the real enemy, the USA and the Western imperialism accurately. Contrary to this optimistic development it is apparent that we have important problems with Russia (Rose \& Munro, 2002).

Putin, attaching priority to the link of "Foreign Politics-Foreign Trade", struggles more to popularize this new understanding. In comparison to the Yeltsin period, a many times more increase in foreign tours and diplomatic contacts have been observed in the Putin era. The countries to which Putin went to show this wide range that the new policy head for and this activeness base. These contries are England and Germany, North Korea and Cuba, Belarus and Azerbaijan (Kapuscinski, 1999).

Putin is a pragmatical leader defending the cooperation with the West. But, he thinks that Russia should strike her attitude at the points that the national interests do not match up with the political attitudes of the West. For instance, the 1995 Chernomyrdin-Gore conversation, which suspended the military trade 
with Iran on account of the expectation of big loans from the West, was given up in the last November. In the meanwhile, Russia went on attack together with a commission formed in the leadership of Putin to regain her position lost in the arms sales in recent years. Of the priority regions The Commonwelth of Independent States comes first in which there are the old 11 Soviet republics except Russia. New and more active policies have been tried to form for Central Asia, Caucasia, Middle East and the Balkans (Cherniavsky, 2000).

The "eastern front" of the foreign policy has been enhanced notably in China, India and Japan. The economic cooperation and especially the energy issues become prominent in the international relations instead of the old ideological cliches and friendship tirades (Ivanov, 2001).

The Islamist radical forces threatening Uzbekistan, Russian minority issues in Kazakhistan, Karabakh and Abkhazia issues in Caucasia and the Russian bases will be among the subjects of which Russia will make use to strenghten her effectiveness in the upcoming period (Cherniavsky, 2000). Duma approved the proposed law as well that forbade the regional governments's getting foreign debts in the second voting. In the voting, 305 deputies used affirmative votes, 5 deputies refrained from a vote and there was none voting against (Buze, 2001).

The proposal shall be sent to the upper house of the parliament, Federation Council after three votes that are going to be taken by Duma according to the basic law. If the proposal passes the Federation Council, too only a few regions in Russia shall have the right of getting foreign debt (Akgonenc, 1994).

Due to the 1998 economic crisis, the fact that each region of Russia got loans seperately made the central government got into a scrape. Rory MacFarquhar of Institute of Russian-European Economics Politics who made economic suggestions for the Russian government and tried to enable the regional governments to set a tough budget, stated that the law banning the republics and the regional governments dependent on the Russian Federation for getting foreign loans was a strong financial policy (Ifrah, 1998).

\section{Conflicts of Interest}

The authors declare no conflicts of interest regarding the publication of this paper.

\section{References}

Akgonenc, O. (1994). The Foreign Policy Goals of the Russian Federation. Euroasia File, 1 .

Aktukun, I. (1995). How to Proceed from the USSR to CIS. Findings for A Marxist Analysis. Istanbul: Sorun Publication.

Aleksandrov, S. K. (1989). Strani Mira (World States). Moscow: Russian Politics-Literature Publication, Politizdat Publications.

Amy, K. (1999). The Enduring Legacy of the KGB in Russian Politics. Problems of Post-Communism, 47, 4.

Aslan, Y. (1997). The New Geopolitical Turkish Belt and Turkey. Ankara: New Turkey. 
Balci, E. (2002). The USA and China. Cumhuriyet Journal.

Behar, B. (1998). Nationalism Theories, The Politics and Relations in Euroasia. Ankara: Turkey Diary.

Blank, S. (1998). New Tendencies in Caucasia Security. Euroasia Etudes, 13.

Brown, A. (1996). The Gorbachev Factor. New York, Oxford University Press.

Brzesinski, Z. (1998). The Big Chess Board, Priority of America and the Geo-Strategic Requirements for This. Moscow.

Buze, O. (2001). Power of Eurasia. Eurasia Option against the Euroasia Geo-Strategy of the US. Aydinlik.

Cecen, A. (2002). National States Internationalism against the Imperialism Globalism. Global Report.

Chase, R., Hill, E., \& Kennedy, P. (2000). The Axis Countries. The New Lines of the American Policy in the Developing World. Istanbul, Sabah Books.

Cherniavsky, S. (2000). The Caucasus Vector of Russian Diplomacy. Central Asia and the Caucasus: Journal of Social and Political Studies, No. 5, 94.

Cohen, A. (1994). New Russian Policy of the US. Euroasian File, Vol. 1, No. 1, Ankara.

Crell, G. (1990). The Asian Policy of the Russians. Istanbul: Toker Publications.

Crozier, B. (2000). The Rise and Fall of the Soviet Empire. Rocklin, CA: Prima Publishing.

Ifrah, G. (1998). The Numeric Symbols Dictionary of the Indian Civilization (4th ed.). VI-The Universal History of the Numbers, Ankara: Nurol-TUBITAK Publications.

Ivanov, I. S. (2001). The Foreign Policy of Russia and the World (Compiled from the Articles and Meetings). Moscow: Russian State University Moscow State University.

Kapuscinski, R. (1999). The Emperorship. Istanbul: Om Publications.

Mansur, R. (1999). Moscow. Series of Visual Travel Guide. Ankara: Dost Bookstore Publications.

Rose, R., \& Munro, N. (2002). Elections without Order. Russia's Challenge to Vladimir Putin. Cambridge: Cambridge University Press. http://www.cambridge.org 